\title{
Systemic Intertextuality. A Morphogenetic Perspective
}

\section{ABSTRACT}

If late modern literary production is structured by any principles rendering order to the otherwise nebular character of the process, this is the idea of intertextuality that paves the way for the dissolution of well entrenched structures, literary conventions and institutionalized canons. By fostering and facilitating the erosion of boundaries between elite and popular culture, mechanisms of intertextuality show that literature is not only a fixed collection of texts, but also a dynamic social system including structured practices of production and reception together with their institutional, cultural and technological determinants. The paper aims to provide a sociologically-oriented model of intertextual relations taking place within the social system of literature. In this context, circulation, dissemination, and recycling of literary motifs is viewed from a perspective of morphogenetic processes which result in the structural elaboration and systemic change due to the mobilization of social, cultural, and economic capitals in an effort to alter pre-existent practices of signification. Consequently, literature is discussed as an intertextual system in statu nascendi, a sphere of social practices that knows no sense of institutional boundaries or structural constraints.

Keywords: intertextuality, system theory, structuration, morphogenesis, social capital, cultural capital. 


\section{INTRODUCTION: METASTASIS AND MORPHOGENESIS}

The notion of intertextuality has enjoyed a long history of academic interest in the fields of literary theory, cultural studies, and sociology of literature. With its origins in the writings of Russian Formalists, the term reverberated in Mikhail Bakhtin's idea of dialogism, as well as late structuralist writings of Gérard Genette, just to be explicitly voiced in Julia Kristeva's poststructuralist re-conceptualization. Regardless of its intellectual origins, the notion of intertextuality is always deployed in order to conceptualize the literary text as a nebular collection of citations and cross-references to other works of culture. Consequently, rather than perceiving it as a finished product, the text is conceived of as an openended system in statu nascendi.

When expressed in sociological terms, our idea of intertextuality gestures towards the networked nature of social-cultural reality, and the intertext itself may be a shorthand term "for culture of endless deconstruction and reconstruction; for polity geared towards the instant processing of new values and public moods; and for a social organisation aiming at the suppression of space and the annihilation of time" (Castells, The Rise of Network Society 501-02). This is not to postulate that the said terms could be used interchangeably, but merely to signal-in a very Bakhtinian fashion-that intertextual relations are inherently historical; namely, embedded within specific forms of social systems, such as network society. In other words, intertextuality is a concept that aims to explain the late modern culture of endless recycling and repetition in which all fixed distinctions, including traditional boundaries between elite and popular culture, are no longer functional or legitimate.

Following Bakhtin's theory, this article wishes to put forward a sociologically-oriented model of intertextual processes that may be deployed in order to characterize the circulation of literary motifs in highly networked societies. Although providing a fully-fledged taxonomy of all conceptualizations of intertextuality goes well beyond the scope of this paper, our argument focuses on the distinction between structural and systemic conceptualizations. Following the aforementioned dichotomy, one is able to observe that our understanding of intertextual relationships involves seeing them either as semiotic cross-references rooted in the synchronic system of language or, conversely, in terms of human experiences and sensibilities that clash and blend in the changeable realities of dialogical networks.

The structural (or structural-metastatic) conceptualization focuses on the capacity of language structures to produce signifying chains 
that render the formation of intertextual relationships possible: "the signifying chain produces texts which carry with them the recollection of the intertextuality which nourishes them" (Eco 24). In other words, the conceptualization is based on the idea of intertextuality as a semiotic potentiality whereby the solid structure of language supplies rules and resources for the circulation of isolated signs and entire literary motifs. Such a possibilistic viewpoint inevitably involves seeing the literary text as a "differential network, a fabric of traces referring endlessly to something other than itself, to other differential traces" (Derrida 81). This differential network is viewed as a disembodied site of textual interrelations, a structure in the strong (i.e. Durkheimian and de Saussurean) meaning of the term. One is, therefore, able to perceive intertextuality as a feature of the language code rooted in the distribution of symbolic relationships that happens objectively; namely, without the reader's conscious participation in the process. "The structure of an organism exists independently of its functioning in a certain specific sense: the parts of the body can be studied when the organism dies, that is, when it has stopped 'functioning'" (Giddens, Central Problems in Social Theory 61). The same observation may apply to the structural perspective on intertextuality: intertextual relations are perceived to dwell in the space of textual potentialities; that is, to exist independently of their actual functioning in the dialogical sphere of human communication and association.

Following the aforementioned postulates, one is tempted to observe that the circulation of textual resources is of a somewhat metastatic character, producing an impression that the flow of literary motifs takes place within the otherwise solid character of language structures. As derived from the Proto-Indo-European root "sta-" (i.e. to stand, to be firm, to be still), an oncological concept of metastasis seems most adequate to metaphorically render the paradox of intertextuality. The oxymoronic combination of meta + stasis (i.e. beyond stillness) shows that - though conceptualized as a solid structure-the differential network of signifying chains produces movement as if literary traces were granted an innate power to migrate from one text to another.

On the other hand, one may refer to the systemic-morphogenetic conceptualization in which it is postulated that societal mechanisms of communication produce the effect of intertextuality. Rather than perceiving them as a potentiality of communication code, the systemicmorphogenetic perspective shows that intertextual relations evolve as a network of actual interactions in which, to use Bakhtin's terminology, "a word is a bridge thrown between myself and another" (Bakhtin and Voloshinov 20). In this specific context, the stress is laid on the societal actuality of human communication which produces chains of dialogical 
interactions. "All utterances are responses to previous utterances and are addressed to specific addressees. It is this addressivity of the word and utterance... which must be the central focus of the study of language" (Allen 20).

This particular understanding gestures towards an idea of morphogenesis; namely, a process of systemic changes due the reoccurrence of individual practices (Archer). In this specific case, "the use of the term 'morphogenesis' to describe the process of social structuring; 'morpho' indicating shape, and 'genesis' signalling that the shaping is the product of social relations" (Archer 166, emphasis mine). When observed from a perspective of intertextuality, the addressivity of language makes sense only when one sees the interconnectivity of literary motifs in the context of individual actions that produce social systems of dialogic communication. Relational signification chains that pave the way for intertextual relations must be elaborated in social processes of communication, involving knowledge and experience sharing, formation of dialogic communities, and horizontal structures of interpersonal interaction. If it was not for the practice of everyday communication, textual possibilities would be left dormant in the potentially infinite reservoir of language.

Concluding these introductory remarks, one could observe that literary metastasis is a logical precondition for literary morphogenesis as the terms represent the dual nature of intertextual processes. Interaction, dialogue, circulation of literary motifs depend on the existence of shared communication codes which, in turn, are not given any other conceivable mode of existence apart from the actuality of social communication.

If we think of any empirical event or phenomenon in a society, anything that is actually happening, is it not always, without exception, a fusion of structures and agents, of operation and action? Show me an agent who is not enmeshed in some structure. Show me a structure which exists apart from individuals. Show me an action which does not participate in societal operation. Show me societal operation not resolving into action. There are neither structureless agents nor agentless structures. (Sztompka, Society in Action 92)

This duality focuses on our idea of intertextuality as an interplay between textual potentialities and their selective usage (or distribution) in actual communication. The latter understanding seems especially conducive for analyses focusing on the role of extra-textual factors (e.g., social networks, financial resources, etc.) in fostering intertextual relations, as it is the case when symbolic resources are breaking the boundaries that used to separate elite and popular culture. In the reality of network society, elite institutions, grass-roots movements (e.g., subcultures), and culture 
industry are mere nodes in the system of flows, including literary themes, capital, and human resources. The underlying "politics of circulation" (Beer) cannot be effectively explored by researching into the model of intertextuality based on purely structural relations. Consequently, one has to refer to more sociologically-oriented conceptualizations to provide a topography of networked intertextuality. The conspicuous predecessor for such a model of intertextual relations is Bakhtin's theory of dialogism.

\section{ON THE SHOULDERS OF BAKHTIN}

The morphogenetic perspective on intertextuality drives us away from the Durkheimian understanding of the literary text as a social fact sui generis; that is, a product of culture that originates in "a relation between two or more texts established through their origins in common codes or through references, echoes or traces" (Kalaga 61). Therefore, one could say that a sociologically-oriented perspective on intertextuality involves interpreting the notion in terms of dialogical practices of literary interpretation and production. In this specific sense, the literary text is a product of social processes of conflict and negotiation that take place in the public sphere understood as a deliberative space of communication, an arena of thought in which different voices come to create the polyphony of cultural production (Habermas). Historically speaking, such a conceptualization is greatly indebted to Bakhtin's persistence in conceptualizing the literary text from a perspective of the historicity of communication systems:

Not only the meaning of the utterance but also the very fact of its performance is of historical and social significance, as, in general, is the fact of its realization in the here and now, in given circumstances, at a certain historical moment, under the conditions of the given social situation. The very presence of the utterance is historically and socially significant. (Bakhtin and Medvedev 120)

Dialogism, stressing the social situatedness of meaningful interactions, is a prerequisite for our systemic-morphogenetic understanding of intertextuality. Even the simplest utterance, not to mention a literary work of art, is given meaning within a specified time-space; it is intertwined within a significant network of social practices and contextual circumstances, including a plethora of political, economic or ideological considerations. More significantly, texts are dialogic, which means that words are given meaning only as a part of everyday practices comprising the flow of the 
social Lebenswelt: "Language acquires life and historically evolves . . in concrete verbal communication, and not in the abstract linguistic system of language, nor in the individual psyche of speakers" (Bakhtin and Voloshinov 19).

As opposed to the structuralist conceptualization, in which the system of language is given an abstract status of a social fact sui generis, the Bakhtinian understanding of language assumes the societal properties of reciprocity and dialogism as a foundation of communication system that paves the way for literary production:

the word is not a material thing but rather the eternally mobile, eternally fickle medium of dialogic interaction. It never gravitates toward a single consciousness or a single voice. The life of the word is contained in its transfer from one mouth to another, from one context to another context, from one social collective to another, from one generation to another generation. In this process the word does not forget its own path and cannot completely free itself from the power of those concrete contexts into which it has entered. When a member of a speaking collective comes upon a word, it is not as a neutral word of language, not as a word free from the aspirations and evaluations of others, uninhabited by others' voices. No, he receives the word from another's voice and filled with that other voice. The word enters his context from another context, permeated with the interpretations of others. His own thought finds the word already inhabited. (Bakhtin 201)

The qualities of reciprocity and dialogism logically presuppose a system whose function is to foster and facilitate the repeatable, institutional character of symbolic communication. Words are shared, meanings are dispersed and distributed across the social tissue, providing individuals and collective agents with texts (i.e. textual forms of expression) that can never be seen as their own appropriations since they all reside in the shared system of communication and exchange (Burzyński, Between the Stage and the Text).

When seen from a perspective of Bakhtin's theory, the system of language is viewed as an entity in statu nascendi due to its historical situatedness in the changeable flow of communicative practices. This form of transformability occurs as morphogenetic processes of systemic elaboration and transformation due to organized social practices. The same could be said of intertextuality: rather than being anchored in the abstract properties of the language structure, the term is conceived of as a coefficient to the evolving network of interpersonal communication in which the exchange of texts is a matter of agential participation in the system of reciprocal interaction. 


\section{LITERATURE AS A SOCIAL SYSTEM}

Bakhtin's understanding of dialogism as a quality shrouded in historicity and reciprocity of interpersonal interaction paves the way for our attempt to conceptualize literature in terms of its systemic nature. The systemic perspective is based on an assumption that literature is not only a collection of self-contained texts, but it also comprises a plethora of mediatory mechanisms whose existence renders intertextual relationships possible. The mediatory mechanisms-such as communication technologies, marketing and advertising, political ideologies-facilitate the circulation of literary motifs, forming symbolic relationships between key institutions of late modern society; namely, the citizen-state, the market, and the sphere of public communication (Lee and LiPuma).

Understanding literature in terms of a social system pays its intellectual debts to Jürgen Habermas's conceptualization of the literary public sphere as an inclusive space of unrestricted debate in which participants are in a position to take part in discussions of art and literature, exercising their right to associate in a form of grass-roots organizations (Habermas). Rules of interpersonal communication (i.e. communicative rationality), or patterns of meaning negotiation are not superimposed upon the participants: on the contrary, as predicted by Archer's theory of morphogenesis, they emerge spontaneously as by-products of repeatable, routinized interactions. Consequently, to refer to Bakhtin's viewpoint one more time, one can observe that the circulation of interpretations comes in the wake of the shared axiology that facilitates reciprocity, trust and an attitude of benevolence towards the Other. "The words we select in any specific situation have an 'otherness' about them: they belong to specific speech genres, they bear the traces of previous utterances. They are also directed towards specific 'others,' specific addressees" (Allen 21).

The social system, as Giddens puts it in The Constitution of Society, could be understood in terms of a structured organization of social practices that are reproduced in time and space. Our intention is to deploy a similar methodology and to see literature in terms of social practices of signification that bind time and space by means of subsuming individuals (e.g., artists, literary critics, readers), social groups (e.g., social movements, avant-garde movements) and institutions (e.g., educational institutions, publishing houses) within the shared spectrum of practices aiming at the creation and dissemination of artistic and cognitive values. Thusly understood, the social system of literature focuses on both isolated social practices and systemic processes of their reproduction. Moreover, the same qualities render a morphogenetic understanding of intertextuality possible. 
Firstly, the notion of intertextuality draws our attention to social practices by which diversified literary texts are engaged in the network of social associations that bind past readings (or interpretations) and present activities within the shared interpretative horizon. In this sense, literary texts are symbolic resources deployed by individuals (and social groups) in their daily exercise of participation in culture. Systemic intertextuality is understood in a purely processual manner as mutually oriented social practices that engage individuals of diversified social backgrounds into relationships of conflict and negotiations in which literary texts are used as symbolic tokens mobilized to create new artistic qualities or achieve other social values.

Secondly, the practice-related nature of the literary social system underscores the role of reproduction processes in recognizing its dynamic character. If our idea of intertextuality preserves a sense of continuity between a number of texts, it is also evident that this sort of continuity must be elaborated upon, worked out in a series of meaning-formation practices. Consequently, the systemic-morphogenetic perspective on intertextuality gestures towards the dilemma of agency and structure, continuity and change, tradition and innovation in the existence of culture conceived of as a sphere of organized human practices (Burzyński, "The Surplus of Structure"). On the one hand, social practices of signification do not take place in a symbolic void but, contrariwise, are immersed in the shared universe of literary motifs, symbols, themes, or clichés. In this sense, Roland Barthes's postulate of the literary text as a "tissue of past citations" pays homage to the spirit of continuity. On the other hand, however, practices of signification are concerned with the societal actuality of communication practices "in which both the debate of the subject and the Other, and the social context, are invested in the same movement" (Barthes 36). In the context of intertextual processes, agents who produce cultural texts are simultaneously structured (or produced) by the very act of their participation in the shared socio-cultural reality. The latter observation brings about the idea of culture as shrouded in duality:

it may be said that from the vantage point of action there exists a parallel "duality of culture." On the one hand, culture provides a pool of resources of action that draws from it the values to set its goals, the norms to specify the means, the symbols to furnish it with meaning, the codes to express its cognitive content, the frames to order its components, the rituals to provide it with continuity and sequence and so forth. In brief culture supplies action with axiological, normative and cognitive orientation.... On the other hand, action is at the same time creatively shaping and reshaping culture, which is not God-given, constant, but rather must be seen as an accumulated product, or preserved sediment of earlier individual and collective action. (Sztompka, Trust 3-4) 
The systemic-morphogenetic perspective shows that intertextual processes bridge the gap between the subjectivity of one's actions and the objective character of literary heritage understood as a pool of already published resources. In other words, intertextuality, as it were, stands astride between the creativeness of interpretation, as well as the rigidity of language and cultural structures.

\section{HIGH CULTURE GOES POP. A MORPHOGENETIC PERSPECTIVE}

The systemic-morphogenetic perspective shows that intertextuality is not merely a "tissue of past quotations," but a tissue of conflicting human experiences, sensibilities and interests given shape in the medium of language. As a result of ongoing social practices, intertextual processes engages both texts and agents who deploy their resources in order to orchestrate the circulation of literary motifs within or between established systems of signification, such as high and popular culture.

Dissolving the boundaries between systems of signification is far from being a purely semiotic process as it involves conflicts and negotiations in which agents struggle to mobilize resources in order to interfere into the existing system of intertextual relations. This postulate supplies the systemic-morphogenetic perspective with yet another observation: the tissue of intertextual relations is hierarchized, which means that certain quotations are repeated more frequently than other references. Nevertheless, this form of hierarchization cannot be derived directly from the shared communication code as it has no innate power to determine the distribution of symbolic resources in the actual use of language. Logically, intertextual processes are orchestrated by the fact that agents participating in the literary social system are granted uneven capacities to mobilize textual and extra-textual resources. Agents involved in the social system of literature deploy resources in order to take part in processes of converting certain values into different ones, as it is the case with converting texts of elite culture into egalitarian products associated with the existence of mass-mediated forms of pop culture. Given the transformational character of the system, it seems that the notion of capital best renders its dynamic capacities (as in the case of converting human labor into economic surplus). In their efforts to influence the distribution of textual references, actors (i.e. individuals and institutions) may deploy three types of resources: financial capital (the market), cultural capital (educational institutions, government regulatory bodies, etc.), social capital (social movements, grass-roots organizations, etc.). 
When intertextuality is perceived from a perspective of diminishing boundaries between high and popular culture, the element of financial capital is of primary importance as it responds to the marketability of mass-mediated forms of art. In this case, one is able to address, as it were, "predatory intertextuality" in which patterns of elite culture are becoming captured, simplified and subsequently re-introduced as homogenized products of mass culture. Predictably, the role of the culture industry is concerned with exerting control over those communication technologies that function as mediatory mechanisms of intertextuality. As opposed to local folk cultures, whose existence is based on exchanging ideas by means of horizontal social ties, the corporate culture industry promotes a hierarchical model of circulation in which the global supply of standardized mass products is fostering the one-to-many model of communication that leaves individuals utterly deprived of opportunities to creatively engage into the circulation of symbolic goods.

In the reality of networkable technologies, social capital proves itself to be a type of resource that may equally enable the demise of boundaries between already existing forms of culture, facilitating the development of intertextual and inter-media processes. Understood as norms and values that propel grass-roots associations (Putnam), social capital is most evident in forms of spontaneous cultural production in which groups of independent artists participate in creating works of literature via the medium of the Internet. This is especially conducive for literary genres that involve collaborative writing (e.g., digital poetry, literary blogosphere, interactive fiction), fostering the formation of online literary communities. Due to the unprecedented capacity of networkable communities to address global audiences, online artists are able to popularize their projects without being forced to invest considerable financial resources into the process. By fostering global online communities, viral spreading of literary texts or themes, spontaneous grass-roots activities may challenge publishing and broadcasting corporations by converting elite texts into more popular narratives that circulate in cyberspace, inspiring myriads of elite and popular artists.

The significance of finances and social capital for the formation of intertextual relationships increases concomitantly with the decrease in the role of cultural capital in reinforcing the traditional boundaries between elite and popular culture. When defined in terms of material and symbolic assets which are conventionally valued as factors promoting social mobility (Bourdieu), institutional cultural capital is observable as the authority of institutions that seek to exert influence on the distribution of cultural goods by evoking the aura of tradition, good taste or a notion of artistic canon. The dissolution of cultural capital occurs most conspicuously in 
the reality of post-traditional culture in which "social forms (structures that limit individual choices, institutions that guard repetitions of routines, patterns of acceptable behavior) can no longer (and are not expected) to keep their shape for long, because they decompose and melt faster than the time it takes to cast them" (Bauman 1). This openly mercurial reality privileges the mobilization of economic and social capital over the stillness of institutional authorities embodied by literary canons or other forms of limitation set upon the system of literature.

\title{
IN PLACE OF CONCLUSIONS
}

Ours is a dynamic, changeable world in which traditional forms of cultural production are subject to metamorphic transformations (Beck) due to the still increasing supply of networkable technologies, globalization, and growing skepticism in metanarratives. Culture, as Manuel Castells aptly concludes,

\begin{abstract}
was historically produced by symbolic interaction in a given space/ time. With time being annihilated and space becoming a space of flows, where all symbols coexist without reference to experience, culture becomes ... an interactive network in the electronic hypertext, mixing everything, and voiding the meaning of any specific message out of this context. ("Materials" 21)
\end{abstract}

This paves the way for a paradigm shift in the field of theorizing intertextuality, a movement from the structural-metastatic conceptualization towards a systemic-morphogenetic notion. In the latter understanding, intertextuality is an effect of networked practices of signification that constitute the social system of literature. Following Bakhtin's formative theory, it shows that intertextuality is a matter of historically-specific interactions, conflicts and negotiations that bind agents who perform their roles in the social system of literature by means of drawing from the multiplicity of textual resources and navigating across spatial, temporal and virtual topographies of social life.

\section{WORKS CiTED}

Allen, Graham. Intertextuality. London: Routledge, 2006. Print. Archer, Margaret S. Realist Social Theory: the Morphogenetic Approach. Cambridge: Cambridge UP, 1995. Print. https://doi.org/10.1017/ CBO9780511557675 
Bakhtin, Mikhail. Problems of Dostoyersky's Poetics. Ed. and trans. Caryl Emerson. Minneapolis: U of Michigan P, 1984. Print.

Bakhtin, Mikhail, and Pavel Medvedev. The Formal Method in Literary Scholarship: A Critical Introduction to Sociological Poetics. Trans. Albert J. Wehrle. Baltimore: Johns Hopkins UP, 1978. Print.

Bakhtin, Mikhail, and Valentin Voloshinov. Marxism and the Philosopby of Language. Trans. Ladislav Matejka and I. R. Titunik. Cambridge, MA: Harvard UP, 1986. Print.

Barthes, Roland. "Theory of the Text." Untying the Text: A Post-Structuralist Reader. Ed. Robert Young. London: Routledge, 1981. 31-47. Print.

Bauman, Zygmunt. Liquid Times. Living in an Age of Uncertainty. Cambridge: Polity, 2007. Print.

Beck, Ulrich. The Metamorphosis of the World. Cambridge: Polity, 2016. Print. Beer, David. Popular Culture and Nerw Media. The Politics of Circulation. New York: Palgrave Macmillan, 2013. Print. https://doi. org/10.1057/9781137270061

Bourdieu, Pierre. "The Forms of Capital." Handbook of Theory and Research for the Sociology of Education. Ed. John G. Richardson. Westport, CT: Greenwood, 1986. 241-58. Print.

Burzyński, Tomasz. Between the Stage and the Text. Agency and Structure in the Analysis of Cultural Change from the Perspectives of Trust and Uncertainty. Katowice: Wydawnictwo UŚ, 2014. Print.

Burzyński, Tomasz. "The Surplus of Structure. Towards the Morphogenetic Approach to Cultural Studies." The Surplus of Culture. Sense, CommonSense, Non-Sense. Ed. Ewa Borkowska and Tomasz Burzyński. Newcastle upon Tyne: Cambridge Scholars, 2011. 223-34. Print.

Castells, Manuel. "Materials for an Explanatory Theory of the Network Society." British Journal of Sociology 51.1 (2000): 5-24. Print. https:// doi.org/10.1080/000713100358408

Castells, Manuel. The Rise of Network Society. Oxford: Blackwell, 2004. Print.

Derrida, Jacques. "Living On/Border Lines." Deconstruction and Criticism. Ed. Harold Bloom et al. London: Routledge \& Kagan Paul, 1979. 75-176. Print.

Eco, Umberto. Semiotics and the Philosophy of Language. Bloomington: Indiana UP, 1984. Print. https://doi.org/10.1007/978-1-349-17338-9

Giddens, Anthony. Central Problems in Social Theory. Action, Structure and Contradiction in Social Analysis. Berkeley: U of California P, 1979. Print. Giddens, Anthony. The Constitution of Society. Outline of the Theory of Structuration. Cambridge: Polity, 1984. Print.

Habermas, Jürgen. The Structural Transformation of the Public Sphere. An Inquiry into a Category of Bourgeoise Society. Trans. Thomas Burger and Frederick Lawrence. Boston: MIT, 1991. Print. 
Kalaga, Wojciech. "Culture and Signification." Britishness and Cultural Studies. Continuity and Change in Narrating the Nation. Ed. Krzysztof Knauer and Simon Murray. Katowice: Wydawnictwo Śląsk, 2000. 51-69. Print.

Lee, Benjamin, and Edward LiPuma. "Cultures of Circulation: The Imaginations of Modernity.” Public Culture 14.1 (2002): 191-213. https://doi.org/10.1215/08992363-14-1-191

Putnam, Robert D. Bowling Alone: The Collapse and Revival of American Community. New York: Simon and Schuster, 2000. Print.

Sztompka, Piotr. Society in Action. The Theory of Social Becoming. Cambridge: Polity, 1991. Print.

Sztompka, Piotr. Trust. A Sociological Theory. Cambridge: Cambridge UP, 1999. Print.

Tomasz Burzyński received his PhD in 2009 from the University of Silesia in Katowice, Poland. He works at the Institute of Literary Studies where he teaches Sociology, Media Studies and Cultural Studies. His research interests include cultural studies and cultural theory, sociology of risk, theories of trust, and discourses of health and illness. Recent publications include: "Sociologizing Automotive Heritage. Traditions of Automobile Folklore and the Challenges of Risk Society" in The Routledge Companion to Automobile Heritage, Culture, and Preservation, ed. J. Clark and B. Stiefel, New York: Routledge, 2020; “Zrzucając maski. Refleksje na temat podmiotowości w świetle procesów (bio) medykalizacji” in $E R(R) G O 37$ (2018).

ORCID: 0000-0003-3780-0020

tomasz.burzynski@us.edu.pl 